\title{
Optimization of Bioreactor Cultivation Parameters by Taguchi Orthogonal Array Design for Enhanced Prodigiosin Production
}

Amera Elmenshawey ${ }^{1}$, Ahmed Abdelrazak ${ }^{1,2^{*}}$, Amr M. Mowafey ${ }^{1}$, Yehia Osman ${ }^{1}$

(1) Faculty of Science, Mansoura University, Egypt

(2) Institute of Process Research \& Development (iPRD), University of Leeds, United Kingdom

* Author to whom correspondence should be addressed.

A.Abdelrazak@Leeds.ac.uk

School of Chemistry

University of Leeds,

Leeds

LS2 9JT

United Kingdom 


\begin{abstract}
One of the major steps toward the industrialization of microbial product(s) is to optimize the cultivation conditions at the large scale bioreactor and successfully control the microbial behavior within large scale production environment. Statistical Design of Experiment was proven to optimize a vast number of microbial processes to achieve robustness and explore possible interactions among the variables. In this research, Taguchi Orthogonal Array was applied to optimize the cultivation condition of a newly isolated Prodigiosin-producing marine bacterial strain, Serratia AM8887, at bioreactor level. Two steps fermentation process was applied; as the productivity was scaled up from shake flask level to a bench top bioreactor (5L) and subsequently to an in-situ sterilization bioreactor system $(20 \mathrm{~L})$ leading to a yield of $7 \mathrm{~g} / \mathrm{L}$ compared to $100 \mathrm{mg} / \mathrm{L}$ prior to optimization confirming that; applying Taguchi experimental design is a reliable and good positive option for the optimization of biotechnological processes.. The produced pigment was purified and the chemical structure was revealed by means of Spectrophotometric, Maas Spectrum (MS), Fourier transform infrared (FT-IR), and proton nuclear magnetic resonance ( $\left.{ }^{1} \mathrm{H}-\mathrm{NMR}\right)$ spectroscopy analysis. The biological activity including antibacterial, antioxidants and cytotoxicity to cancer cells line of the pigment were explored. The pigment showed very characteristic features that could helpful in food, pharmaceuticals and/or textile industries.
\end{abstract}

Keywords; Bioreactor, Taguchi, Prodigiosin, Serratia, Process Development 


\section{Introduction}

Prodigiosin (PG) attracted much research recently due to it's a clinical importance. It is a secondary metabolite of some bacteria such as Serratia sp., Pseudomonas sp. and Vibrio sp. [1] [2]. PG was reported to have antifungal, antibacterial, antimalarial, antiprotozoal and anticancer activities [3]. More importantly, PG was reported to induce apoptosis in different human hematopietic tumor cell lines with no impact on nonmalignant cell lines [4].

Producing enough amounts of any microbial metabolite constitute a great challenge to industrial microbiology. This is because conventional optimization strategies are not only time consuming, require more experimental data sets but it cannot provide information about the mutual interactions of the parameters. The modern procedures depending on design of experiments (DOE) and statistical tools are more helpful in gaining new insights into the optimization conditions in a relatively few trials [5]. Among different statistical tools, Taguchi experimental design offers distinct advantages. It is a fast and considerable way of optimization conferring remarkable outcome in simultaneous study of many factors. It also makes imprint in quality products supplemented with better process execution, and rendering high yield and better stability [6].

The main target of this study was to optimize and scale up the production of PG from a local isolate of bacterial strain, Serratia AM8887, which has been documented to produce significant amounts of PG [7]. The production was optimized at Bioreactor scale (20L) in terms of pH, temperature and dissolved oxygen levels via applying a Taguchi matrix. Upon optimization, the pigment was extracted and screened for its biological activity. 


\section{Material and Methods}

\subsection{Strain and Cultivation Conditions:}

The selected bacterial strain, was previously isolated from Red Sea Sediments, was identified as Serratia AM8887 (GenBank accession number KU726587) based on the morphological and 16S rRNA gene sequencing and analyzing. For PG production, the isolate was inoculated to the previously generated production medium which consisted of; Sucrose $6 \mathrm{~g} / 1$, Glycerol 6 $\mathrm{g} / 1$, Fertilizer Waste $12 \mathrm{~g} / \mathrm{l}$ and $\mathrm{NaCl} 15 \mathrm{~g} / \mathrm{l}$ [7]. The organism was cultivated at an agitation speed of $180 \mathrm{rpm}$ and $25^{\circ} \mathrm{C}$ with a $\mathrm{pH}$ of 6.5 for $48 \mathrm{hrs}$ in a $250 \mathrm{~mL}$ Erlenmeyer flask containing $100 \mathrm{ml}$ of the generated production medium.

\subsection{Optimization of Physico-Chemical parameters controlling PG production in bioreactor}

A batch runs were performed, according the developed Taguchi matrix, using Eppendorf - New Brunswick 5L Rushton turbine Stirred Tank Bioreactor (STR) with a working volume of 3L. After sterilization, the bioreactor was set up as described in the manufacturer's instructions. Taguchi matrix was applied to determine the optimum level of $\mathrm{pH}$, Temperature and Dissolved Oxygen (DO) which control bacterial growth and PG production. DO values were maintained constant by applying cascade control. The design included nine batch fermentations; each was prepared in $2.7 \mathrm{~L}$ of the PG production medium and incubated according to the condition of each trial as shown in Table 1. Seed culture was prepared as $300 \mathrm{ml}$ medium with the same nutrients concentrations of the production medium and incubated in orbital shaker incubator at $25^{\circ} \mathrm{C}$ and $180 \mathrm{rpm}$ for $48 \mathrm{hrs}$ then transferred to the bioreactor.

The bioreactor is equipped with $\mathrm{pH}$ probe, oxygen probe, foam sensor and stirrer of two-six bladed Rushton turbines. For controlled $\mathrm{pH}$ cultivations, the $\mathrm{pH}$ was maintained by addition of $2 \mathrm{M} \mathrm{NaOH}$ and $2 \mathrm{M} \mathrm{H}_{3} \mathrm{PO}_{4}$ solution.

Taguchi experimental design, a standard orthogonal array L9 $\left(3^{3}\right)$, was used to examine three factors in three levels. The L and the subscript (9) represent the Latin square and the number of experimental runs respectively. The levels of the factors studied and the layout of the L9 
Taguchi's orthogonal array are shown in Tables 1 and 2 respectively. The experimental results were analyzed to calculate the main effects of the factors; the analysis of variance technique was then applied to determine which factors were statistically significant. The optimal conditions were determined by combining the levels of factors that had the highest main effect value. All calculations were performed using Design Expert 8.0 statistical package (StatEase, Inc, Minneapolis, MN,USA) [8].

Table 1: Factors and their levels employed in the Taguchi's experimental design for bacterial growth and Prodigiosin production (PG) at Bioreactor Level

\begin{tabular}{|c|ccc|}
\hline \multirow{2}{*}{ Factors } & \multicolumn{3}{|c|}{ Levels } \\
& $\mathbf{1}$ & $\mathbf{2}$ & $\mathbf{3}$ \\
\cline { 2 - 4 } & 6 & 7 & 8 \\
pH & 20 & 30 \\
Temperature $\left({ }^{\circ} \mathbf{C}\right)$ & 10 & 30 & 50 \\
Dissolved oxygen (\%) & 10 & & \\
\hline
\end{tabular}

Upon determining the optimum cultivation conditions; the cells were transferred to a $20 \mathrm{~L}$ CelliGen ${ }^{\circledR} 510$ stainless steel Bioreactor for a pilot scale production of the optimized PG. The InSitu Sterilization Fermenter was set up as described in the manufacturer's instructions. All the conditions were monitored in addition to sample withdrawing at time intervals for off line readings and estimation of growth and pigment production over the run time.

The exact amount of PG was estimated using the recently method developed by [9], with authentic Prodigiosin hydrochloride (Sigma, Aldrich UK) as a standard to generate the standard curve.

\subsection{Pigment extraction and purification}

Extraction of pigment from bacteria was performed according to the method described by [10] with some modification. Scrapping $1 \mathrm{gm}$ of bacterial cells from LB agar plates and suspended in $9 \mathrm{ml}$ of ethanol. Prodigiosin was then extracted from the cells by shaking this suspension for $1 \mathrm{hr}$ 
followed by centrifugation. The supernatant was then filtered through a $0.20 \mu \mathrm{m}$ filter and concentrated at room temperature in the dark. Pigment produced by the bacteria was purified according to the method described by [11] with some modification.

After extraction, the crude pigment was dissolved in ethanol then the solution passed through silica balanced gel (230-400) mesh particle size and then the adsorbed pigment was eluted with $10 \mathrm{M}$ ethyl acetate to get pure pigment and then concentrated by rotatory evaporator at $50^{\circ} \mathrm{C}$, which then analyzed by scanning in UNICAM UV-Visible spectrophotometer to detect the maximum absorbance of Prodigiosin with scanning range from (400-600) [12].

\subsection{Chemical characterization of Prodigiosin}

The chemical structure and molecular weight of the produced Prodigiosin by the isolate Serratia AM8887 were estimated by the following methods;

\subsubsection{Nuclear Magnetic Resonance (NMR) Spectroscopy}

The purified pigment was suspended in deuterochloroform $\left(\mathrm{CDCl}_{3}\right)$. By using model (JEOL NMR ECA-500) at $500 \mathrm{MHZ}$, the ${ }^{1} \mathrm{H}$ NMR spectra of sample was obtained. The chemical shift scale was in parts per million (ppm) [2].

\subsubsection{Fourier Transform Infrared (FTIR) Spectroscopy}

The FT-IR spectrum of the Prodigiosin was recorded with a spectrometer (Perkin Elmer, USA).in the range of $4000-400 \mathrm{~cm}^{-1}[13]$.

\subsubsection{Mass Spectrum of Prodigiosin}

The molecular weight of the pigment was determined by using mass spectrometry by using model DSQ [14]. 


\subsection{Evaluation of in vitro antimicrobial activity of Prodigiosin}

The antimicrobial activities of Prodigiosin (crude and pure) were studied on LB agar by the disc diffusion technique against clinical isolates of Bacillus subtilis, Staphylococcus epidermidis, Escherichia coli, Pseudomonas aeruginosa, klebsiella pneumoniae, Candida albicans, Erwinia carotovora, Methicillin resistant Staphylococcus aureus (MRSA), Proteus vulgaris, Streptococcus pyogenes, staphylococcus aureus and Enterobacter cloacae. All the isolates were obtained from Mansoura University General Hospital, Egypt.

Sterile filter paper discs $(6 \mathrm{~mm})$ were individually immersed in $500 \mu$ l of ethanol extract of Prodigiosin and ethanol was taken as control. All the discs were dried and placed on the surface of the test bacterial and fungal lawn. Following 18 to $24 \mathrm{hrs}$ of incubation at $37^{\circ} \mathrm{C}$, the plates were examined for the zones of inhibition [15].

\subsection{Evaluation of antioxidant activity of Prodigiosin}

The effect of Prodigiosin on 1,1-diphenyl-2-picrilhydrazyl (DPPH) (Fluka, Switzerland) radical was estimated using the method described by [16]. Five dilutions of the pigment were prepared in methanol. $1 \mathrm{ml}$ of the prepared concentrations of the tested pigment was added to $1 \mathrm{ml}$ of $\mathrm{DPPH}^{-}(0.135 \mathrm{mM})$. Absorbance was measured at $517 \mathrm{~nm}$ after 30 minutes of incubation at exclusion of light. A solution free of the pigment was used as a blank and contained methanol instead of the sample. The percentage of remaining DPPH ${ }^{*}$ of each tested concentration at the steady state was calculated as follows:

$$
\% \mathrm{DPPH}^{\cdot} \text { remaining }=\left[\mathrm{DPPH}^{\circ}\right]_{\mathrm{T}} /\left[\mathrm{DPPH}^{*}\right]_{\mathrm{T}=0} \mathrm{X} 100
$$

These values were plotted against $\mathrm{mg}$ of Prodigiosin to show the amount of antioxidant necessary to decrease the initial $\mathrm{DPPH}^{*}$ concentration by $50 \%$ ( $\left.\mathrm{IC}_{50}\right)$. Catechine, Ascorbic acid and gallic acid were used as references to compare with.

2.6 Evaluation of cytotoxicity effects of purified Prodigiosin against MCF-7 cell line and HepG2 cell line 
These experiments were performed to test the potentiality of the obtained PG to inhibit two different cancer cells including; Breast and Liver cancer cells.

Mammalian cell line: MCF-7 cells, HepG-2 cell line (human breast cancer cell line and human liver cancer cell line were obtained from VACSERA tissue culture unit, Cairo, Egypt).

Cell line propagation: The cells were propagated in Dulbecco's modified Eagle's medium (DMEM) supplemented with 10\% heat inactivated fetal bovine serum, 1\% L-glutamine, HEPES buffer and $50 \mu \mathrm{g} / \mathrm{ml}$ gentamycin. All cells were maintained at $37^{\circ} \mathrm{C}$ in humidified atmosphere with $5 \% \mathrm{Co}_{2}$ and were sub cultured two times a week. Cell toxicity was monitored by determining the effect of the test samples on cell morphology and cell viability.

Cytotoxicity evaluation using viability assay: For cytotoxicity assay, the cells were seeded in 96-well plate at a cell concentration of $1 \times 10^{4}$ cell per well in $100 \mu 1$ of growth medium. Fresh medium containing different concentration of the test sample was added after 24hrs of seeding. Serial two-fold dilutions of the tested chemical compound (PG) were added to confluent cell monolayer's dispensed into 96-well, flat-bottomed micro titer plates (Falcon, NJ, USA) using a multichannel pipette. The micro titer plates were incubated at $37^{\circ} \mathrm{C}$ in a humidified incubator with $5 \% \mathrm{CO}_{2}$ for a period of $48 \mathrm{hrs}$. Three wells were used for each concentration of the test sample. Control cells were incubated without test sample and with or without DMSO. The little percentage of DMSO present in the wells (maximal 0.1\%) was found not to affecting the experiment. After incubation of the cell for $24 \mathrm{hrs}$ at $37^{\circ} \mathrm{C}$, various concentration of the tested pigment $(50,25,12.5,6.25,3.125,1.56 \mu \mathrm{g})$ were added, and the incubation was continued for $48 \mathrm{hrs}$ and viable cells yield was determined by a colorimetric methodusing 3-(4, 5dimethylthiazol-2-yl)-2, 5-diphenyltetrazolium bromide (MTT) assay.

In brief, after the ends of the incubation period, media were aspirated and the crystal violet solution $(1 \%)$ was added to each well for at least 30 minutes. The stain was removed and the plates were rinsed using tap water until all excess stain is removed. Glacial acetic acid (30\%) was then added to all wells and mixed thoroughly, and then the absorbance of the plates were measured after gently shaken on micro plate reader (TECAN, Inc.), using a test wavelength of $490 \mathrm{~nm}$. All results were corrected for background detected in wells without added stain. Treated samples were compared with the cell control in the absence of the tested compound. All experiments were carried out in triplicate. The cell cytotoxic effect of each tested compound was calculated $[17,18]$. 


\section{Results}

\subsection{Statistical Optimization Using Taguchi Orthogonal Array Design}

In this research, the influence of 3 factors on the bacterial growth of Serratia sp AM8887 and its PG production were tested in Taguchi experimental design in 9 runs as shown in Table 2. Nine different trials, each with its unique combination, were performed to estimate the optimum conditions for PG production at Bioreactor level. The values of the targets to be optimized (growth and pigment concentration) were calculated and analyzed (Table 2).

Table 2: $\mathrm{L}_{9}$ orthogonal array of Taguchi experimental design and corresponding responses

\begin{tabular}{|c|ccc|cc|}
\hline \multirow{2}{*}{ Run } & \multicolumn{3}{|c|}{ Variables } & \multicolumn{2}{c|}{ Responses } \\
\cline { 2 - 6 } & $\mathbf{p H}$ & $\begin{array}{c}\text { Temperature } \\
\left.\text { ( }{ }^{\circ} \mathbf{C}\right)\end{array}$ & $\begin{array}{c}\text { Dissolved } \\
\text { oxygen (\%) }\end{array}$ & O.D $\mathbf{6 2 0}$ & PG Conc. (mg/l) \\
1 & & 10 & 10 & 2.49 & 347.30 \\
2 & 6 & 20 & 30 & 2.53 & 421.36 \\
3 & 6 & 30 & 50 & 1.96 & 449.14 \\
4 & 6 & 10 & 30 & 1.59 & 57.88 \\
5 & 7 & 20 & 50 & 1.40 & 252.35 \\
6 & 7 & 30 & 10 & 1.89 & 208.37 \\
7 & 7 & 10 & 50 & 1.49 & 720.00 \\
8 & 8 & 20 & 10 & 1.98 & $\mathbf{2 3 3 8 . 0 0}$ \\
9 & 8 & 30 & 30 & 1.14 & 81.00 \\
\hline
\end{tabular}

The efficiency of PG production by Serratia sp ranging from $57.88-1338 \mathrm{mg} / \mathrm{l}$ corresponding to the combined effect of the three factors in their specific ranges. The experimental results suggest that these factors at optimum level strongly support the production of Prodigiosin. In trial number 4; the lowest production of PG was observed $(57.88 \mathrm{mg} / 1)$, while in trial number 8 ; the highest amount of PG (2338 mg/l) was observed. 
The outcomes of the fermentation runs were analyzed by statistical software package Design Expert 8.0. The signal-to-noise ratio $(\mathrm{S} / \mathrm{N})$, which is the logarithmic function of desired output, served as objective function for optimization. For each run, $\mathrm{S} / \mathrm{N}$ ratio corresponding to largerthe-better objective function as shown in Table 3.

Table 3: S/N Ratios and Means for each response of $\mathrm{L}_{9}$ Taguchi orthogonal array design

\begin{tabular}{|c|cc|cc|}
\hline \multirow{2}{*}{ Run/expt.no } & \multicolumn{3}{|c|}{ O.D $_{\text {620 }}$} & \multicolumn{2}{c|}{ PG Conc. (mg/l) } \\
\cline { 2 - 5 } & S/N ratio & Mean & S/N ratio & Mean \\
1 & 7.92399 & 2.4900 & 50.8141 & 347.30 \\
2 & 8.08641 & 2.5370 & 52.4931 & 421.36 \\
3 & 5.84512 & 1.9600 & 53.0476 & 449.14 \\
4 & 4.04977 & 1.5940 & 35.2506 & 57.88 \\
5 & 2.95538 & 1.4053 & 48.0401 & 252.35 \\
6 & 5.54760 & 1.8940 & 46.3767 & 208.37 \\
7 & 3.46373 & 1.4900 & 57.1466 & 720.00 \\
8 & 5.94207 & 1.9820 & 62.5291 & 2338.00 \\
9 & 1.18369 & 1.1460 & 38.1697 & 81.00 \\
\hline
\end{tabular}

A main effects plot was used to examine differences between level means for one or more factors. There is a main effect when different levels of a factor affect the response differently. A main effects plot for $\mathrm{S} / \mathrm{N}$ Ratios and means graphs the response for each factor level connected by a line (Figure 1). 
a)

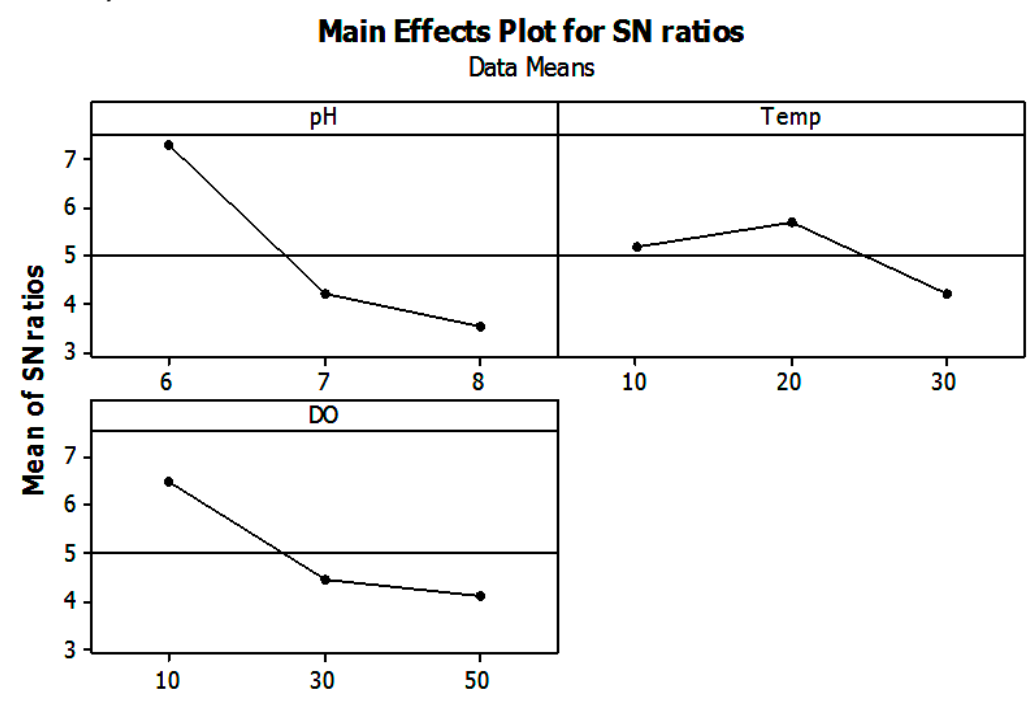

Signal-to-noise: Larger is better

b)

Main Effects Plot for SN ratios Data Means

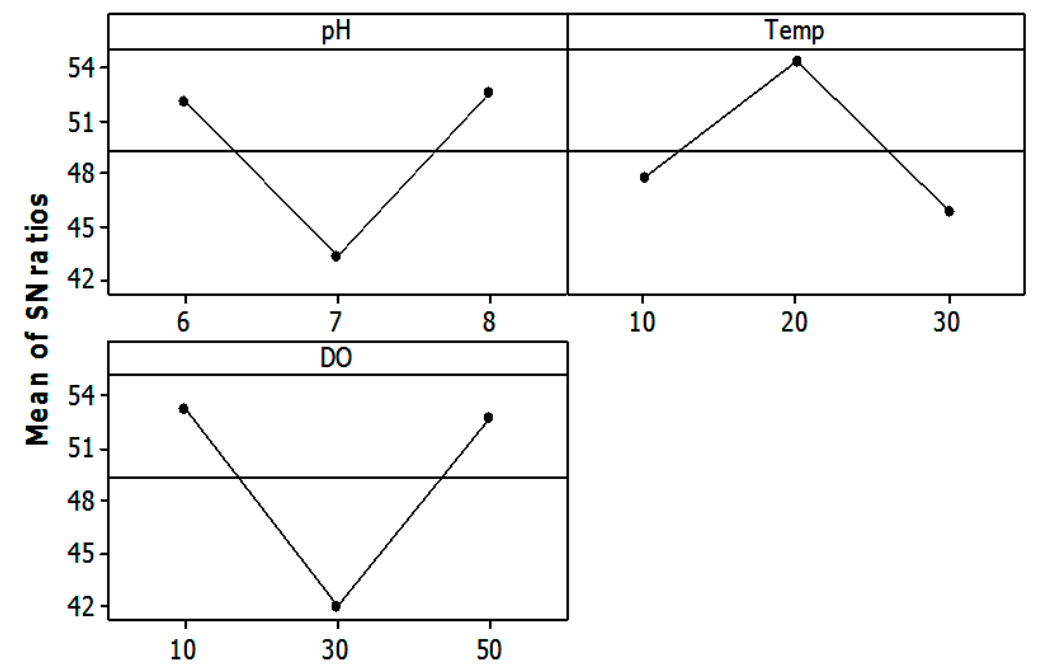

Signal-to-noise: Larger is better

Figure 1: Main effect plots for S/N ratios with larger-the-better objective function of Taguchi optimized fermentation process parameters. a) Main effect plot for growth and b) Main effect plot for pigment production

The Taguchi optimized fermentation process parameters are shown in Figure $1(\mathrm{a}, \mathrm{b})$. The best process parameters for bacterial growth was $\mathrm{pH} 6$, temperature $20^{\circ} \mathrm{C}$ and dissolved oxygen $10 \%$ as shown in Figure 1a while the best process parameters for PG production was $\mathrm{pH} 8$, temperature $20^{\circ} \mathrm{C}$ and dissolved oxygen $10 \%$ as shown in Figure $1 \mathrm{~b}$. 
The factors affecting the bacterial growth can be ranked as $\mathrm{pH}$ then dissolved oxygen and finally temperature while the factors affecting the PG production can be ranked as dissolved oxygen then $\mathrm{pH}$ and finally temperature as shown in Table 4.

Table 4: Impact of fermentation factors and their assigned levels on bacterial growth and PG production

\begin{tabular}{|c|c|c|c|c|c|c|c|c|}
\hline \multirow{2}{*}{ Factor } & \multicolumn{4}{|c|}{ O.D 620} & \multicolumn{4}{|c|}{ PG Conc (mg/l) } \\
\hline & Level 1 & Level 2 & Level 3 & Rank & Level 1 & Level 2 & Level 3 & Rank \\
\hline $\mathbf{p H}$ & 7.285 & 4.184 & 3.530 & 1 & 52.12 & 43.22 & 52.62 & 2 \\
\hline Temperature $\left({ }^{\circ} \mathrm{C}\right)$ & 5.146 & 5.661 & 4.192 & 3 & 47.74 & 54.35 & 45.86 & 3 \\
\hline $\begin{array}{c}\text { Dissolved oxygen } \\
(\%)\end{array}$ & 6.471 & 4.440 & 4.088 & 2 & 53.24 & 41.97 & 52.74 & 1 \\
\hline
\end{tabular}

The experimental data revealed that; selected level 1 of $\mathrm{pH}$ and dissolved oxygen were observed to be optimum for bacterial growth whereas for temperature, selected level 2 was observed to be preferred for bacterial growth.

The experimental data revealed that level 3 of $\mathrm{pH}$, level 2 of temperature and level 1 of dissolved oxygen were observed to be optimum for PG production. Using the Response Optimizer tool in the software (a tool applied to predict the optimum conditions); the optimum suggested by the software to attain the maximum growth and productivity was; Temperature $20^{\circ} \mathrm{C}, \mathrm{pH}=8.5$ and Dissolved Oxygen $=5 \%$

In Taguchi approach, ANOVA is used to analyze the results of the performed experiments and determine how much variation that each factor has contributed. By studying the main effects of each of the factors, the general trends of the influence of the factors towards the process can be distinguished. Analysis of the data for the determination of significant parameters was performed and the results are summarized in Table 5. 
Table 5: Analysis of variance (ANOVA) in $\mathrm{L}_{9}\left(3^{3}\right)$ orthogonal array of designed experiments

\begin{tabular}{|c|c|c|c|c|c|c|}
\hline Source & DF & SS & MS & F-Value & Prop. $(\mathrm{P})>\mathrm{F}$ & $\begin{array}{c}\text { Percentage } \\
\text { contribution } \%\end{array}$ \\
\hline pH & 2 & 27519 & 13760 & 1.93 & 0.341 & $34.99 \%$ \\
\hline $\begin{array}{c}\text { Temperature } \\
\left({ }^{\circ} \mathrm{C}\right)\end{array}$ & 2 & 17785 & 8892 & 1.25 & 0.445 & $22.62 \%$ \\
\hline $\begin{array}{l}\text { Dissolved oxygen } \\
(\%)\end{array}$ & 2 & 19088 & 9544 & 1.34 & 0.427 & $24.27 \%$ \\
\hline Residual Error & 2 & 14234 & 7117 & & & \\
\hline Total & 8 & 78626 & & & & \\
\hline
\end{tabular}

From the calculated ratios $(\mathrm{F}), \mathrm{pH}$ was found to be the most significant factor followed by dissolved oxygen (DO) and temperature respectively.

\subsection{Batch run in a 20L In-Situ Sterilization bioreactor system}

The growth and productivity curve within the bioreactor were calculated and the result obtained was summarized in Figure 2, as the maximum production of PG was $7316 \mathrm{mg} / \mathrm{l}$ achieved after $19 \mathrm{hrs}$ from inoculating the bioreactor.

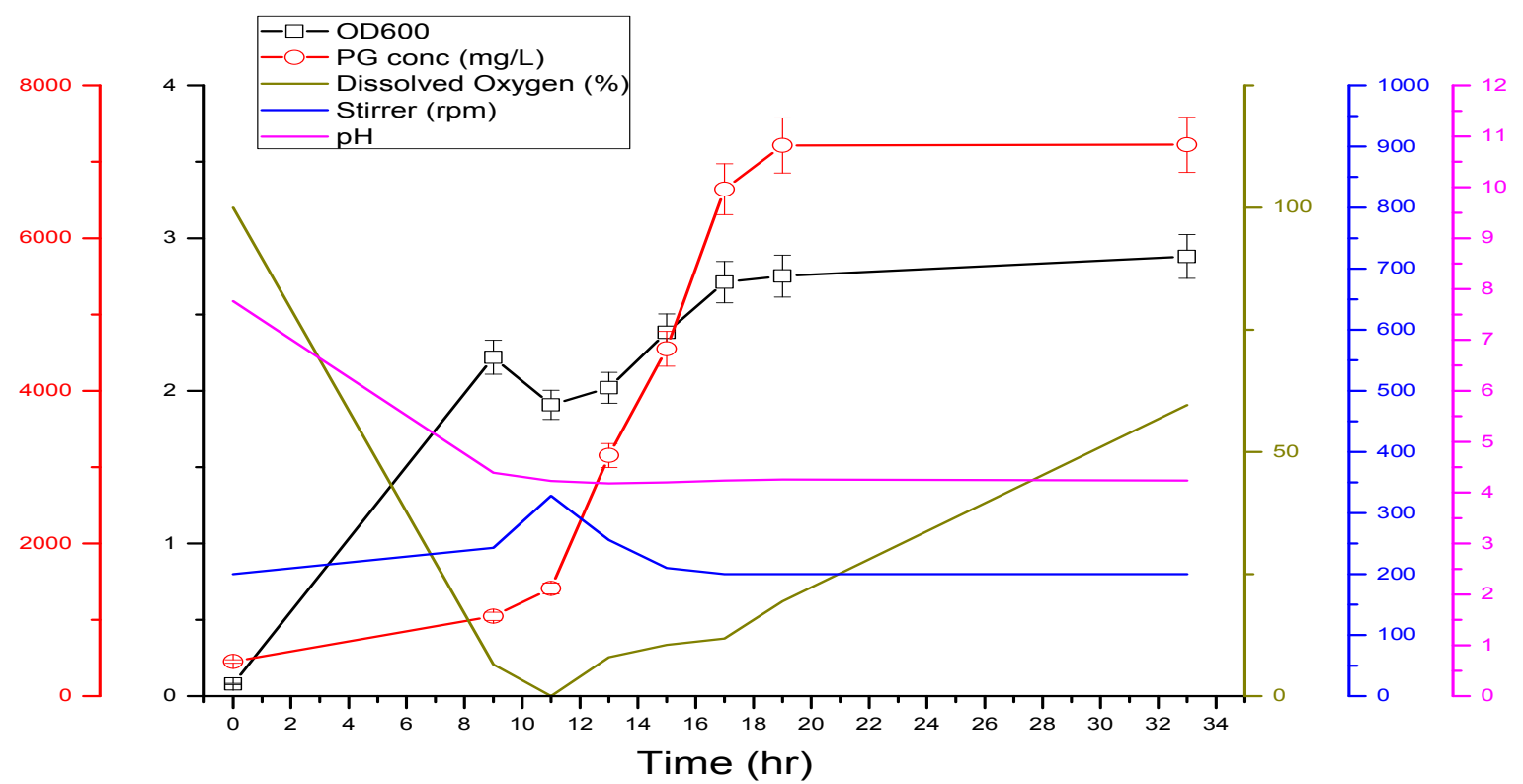

Figure 2: Time trajectory for growth and productivity of Serratia sp within In-Situ Sterilization bioreactor on the optimized production medium under precise condition $\left(20^{\circ} \mathrm{C}\right.$, controlled dissolved oxygen $5 \%$ and $\left.\mathrm{pH} 8.5\right)$ 


\subsection{Scanning spectrophotometer for the produced pigment}

After extraction and purification of the produced pigment; the pigment was analyzed by scanning spectrophotometer in a UV-Visible spectrophotometer to detect the maximum absorbance of Prodigiosin and the scanning range from $(400-600 \mathrm{~nm})$. The Prodigiosin pigment showed a characteristic peak at $535 \mathrm{~nm}$ in absolute ethanol as shown in Figure S1.

\subsection{Chemical structure of Prodigiosin by ${ }^{1} H-N M R$ spectroscopy}

For determination the structural composition of Prodigiosin, proton NMR analysis was applied. The ${ }^{1}$ H-NMR spectra was detected for Prodigiosin which produced by the isolate under investigation as shown in Table 6. The ${ }^{1} \mathrm{H}-\mathrm{NMR}$ spectroscopic data verified the pigment to be Prodigiosin. The ${ }^{1} \mathrm{H}-\mathrm{NMR}$ data were summarized as ${ }^{1} \mathrm{HNMR}\left(\mathrm{CDCl}_{3}, 500 \mathrm{MHz}\right), 4.1$ (s, $3 \mathrm{H}$, $\left.\mathrm{OCH}_{3}\right), 2.31\left(\mathrm{~s}, 3 \mathrm{H}, \mathrm{CH}_{3}\right), 1.51-1.65\left(\mathrm{~m}, 8 \mathrm{H}, 4 \mathrm{CH}_{2}\right), 0.9\left(\mathrm{~s}, 3 \mathrm{H}, \mathrm{CH}_{3}\right), 5.31(\mathrm{~s}, 1 \mathrm{H}, \mathrm{CH}), 7.25-7.56$ $(\mathrm{m}, 5 \mathrm{H}, \mathrm{Ar}-\mathrm{H})$ which confirmed the structure of Prodigiosin (5[(3-methoxy-5-pyrrol-2-ylidenepyrrol-2-ylidene)-methyl]-2-methyl-3-pentyl-1Hpyrrole) as shown in Figure S2.

Table 6: Data of NMR spectra (d, ppm) of Prodigiosin, obtained in this study and those reported in literature

\begin{tabular}{|c|c|c|c|}
\hline $\begin{array}{c}\text { Pigment } \\
\text { M 323.5 Da[19] }\end{array}$ & $\begin{array}{c}\text { Pigment } \\
\text { M 323 Da[20] }\end{array}$ & $\begin{array}{c}\text { Pigment } \\
\text { M 322.9 Da[21] }\end{array}$ & $\begin{array}{c}\text { Pigment } \\
\text { M 323.1 Da } \\
\text { The present study }\end{array}$ \\
\hline 12.44 & - & - & - \\
12.54 & - & - & - \\
- & - & 7.55 & 7.52 \\
7.23 & 7.26 & 7.27 & - \\
6.95 & 6.99 & 6.99 & - \\
6.92 & 6.95 & - & - \\
6.69 & 6.71 & 6.68 & - \\
6.35 & 6.39 & 6.35 & - \\
6.08 & 6.11 & 6.08 & 4.18 \\
4.01 & 4.04 & 4.00 & 2.32 \\
2.76 & 2.58 & 2.55 & 2.30 \\
2.39 & 2.44 & 2.40 & 1.9 \\
1.53 & 1.59 & 1.60 & 1.33 \\
1.30 & 1.34 & 1.33 & 1.30 \\
1.32 & 1.31 & 1.31 & 0.90 \\
0.89 & 0.93 & 0.93 & - \\
\hline
\end{tabular}




\subsection{Fourier Transform Infrared (FTIR) Spectroscopy for the produced Prodigiosin}

The FTIR spectrum for the Prodigiosin showed bands at $2859 \mathrm{~cm}^{-1}$ (methylene group)and $2926 \mathrm{~cm}^{-1}$ (amide group $\mathrm{NH}$ ) while absorption band at $1631 \mathrm{~cm}^{-1}$ corresponded to $(\mathrm{C}=\mathrm{C})$, $1127 \mathrm{~cm}^{-1}(\mathrm{C}-\mathrm{O}-\mathrm{C})$ and $1658 \mathrm{~cm}^{-1}$ corresponded to $(\mathrm{C}=\mathrm{N})$ as shown in Figure $\mathrm{S} 3$.

\subsection{Mass Spectrum of the produced Prodigiosin}

The molecular weight of the pigment was determined by using mass spectrometry which corresponding to $323.1 \mathrm{Da}$ as shown in Figure S4 which agreed with the result obtained by [14].

\subsection{Evaluation of in vitro antimicrobial activity of produced Prodigiosin}

By applying the disc-agar diffusion technique, it was observed that the prodigiosin produced by the isolate Serratia AM8887 was able to inhibit the growth of some antibiotic resistant bacterial strains. As indicated in Table S5, whereas, Fungistatic activity was observed against Candida albicans. Prodigiosin possesses antibacterial activity against gram positive bacteria like Bacillus subtilis, Methicillin resistant Staphylococcus aureus (MRSA) and streptococcus pyogenes and against gram negative bacteria like Escherichia coli, Enterobacter cloacae, klebsiella pneumonia and Erwinia carotovora.

3.8 Antioxidant activity of the produced Prodigiosin by using DPPH radical (1, 1-diphenyl-2picrilhydrazyl) assay

The role of antioxidant is to remove free radical by donating hydrogen to free radicals in its reduction to an unreactive species. Prodigiosin which extracted from Serratia sp was shown an antioxidant activity by reducing DPPH radical (violet in color) into diphenylpicrylhydrazine (yellow in color) by donating hydrogen or electron. There was a significant association could be found between the concentration of Prodigiosin and percentage of inhibition. These values were plotted against mg of pigment to show the amount of antioxidant necessary to decrease the initial 
$\mathrm{DPPH}^{*}$ concentration by $50 \%$ ( $\left.\mathrm{IC}_{50}\right)$. Catechine, Ascorbic acid and gallic acid were used as references as shown in Table 7.

Table 7: Antioxidant activity of Prodigiosin (PG)

\begin{tabular}{|l|c|}
\hline \multicolumn{1}{|c|}{ Substances } & Conc $(\mathrm{mg} / \mathrm{ml})$ \\
\hline Prodigiosin (PG) & $0.034( \pm 0.002)$ \\
Catechine & $0.018( \pm 0.001)$ \\
Ascorbic acid & $0.044( \pm 0.001)$ \\
Gallic acid & $0.038( \pm 0.001)$ \\
\hline
\end{tabular}

According to the obtained results; the amount of Prodigiosin necessary to decrease the initial $\mathrm{DPPH}^{*}$ concentration by $50 \%$ ( $\mathrm{IC}_{50}$ ) was $0.034 \mathrm{mg} / \mathrm{ml}$ indicating that the Prodigiosin considered as an antioxidant agent stronger than gallic acid and ascorbic acid.

3.9 Cytotoxic Activity of the produced Prodigiosin against breast cancer cell line (MCF-7) and liver cancer cell line (HepG-2)

Prodigiosin from Serratia sp have exerted visible cytotoxic effect against breast cancer cell line (MCF-7) and liver cancer cell line (HeG-2).

Calculation of the $\mathrm{IC}_{50}$ required the use of concentration gradients ranged from (zero - 50) $\mu \mathrm{g} / \mathrm{ml}$. The $\mathrm{IC}_{50}$ values were calculated for the pure Prodigiosin and found to be $5.4 \mu \mathrm{g} / \mathrm{ml}( \pm 0.5)$ against HepG-2cell line and $8.73 \mu \mathrm{g} / \mathrm{ml}( \pm 0.9)$ against the MCF-7 breast cell line. 


\section{Discussion}

Prodigiosin (PG) is an alkaloid secondary metabolite, with an exceptional tripyrrole chemical structure, can be produced by certain strains of Serratia sp. additionally strains of other genera of marine bacteria, for example, Pseudomonas sp. and Vibrio sp. The pigment was reported to have antifungal, antibacterial, antimalarial, antiprotozoal and anticancer activities [1][2].

Serratia AM8887 was previously isolated from deep sea core sediments of the Red Sea and was reported to be a potential high PG producer with approximately $100 \mathrm{mg} / \mathrm{L}$ when growing on a combination of wastes [7].

As a step forward in the direction of PG production scaling up; the productivity of the isolate Serratia AM8887 was optimized at bioreactor level via two steps sequential fermentation process. In the first step; the optimum levels of $\mathrm{pH}$, Temperature and Dissolved Oxygen (DO) were addressed in a bench top $3 \mathrm{~L}$ bioreactor with accurate control and online monitoring of the selected variables to be optimized. To achieve this target; Taguchi approach of orthogonal array experimental design was applied generating a matrix of 9 trials each with its own unique combination. The obtained data were exposed to a Multi-Way ANOVA statistical analysis to generate an optimization model which was used to determine the optimum possible combination and to determine the significance of effect of each variable. Taguchi experimental design involves a study of a given system by a set of factors over a specific region of interest (levels) by identifying the influence of individual factors, establishing the relationship between variables and also the performance at the optimum levels. By studying the main effects of each of the factors, the levels of factors to produce the best results can be predicted [22]. The optimum bioreactor cultivation condition were predicted to be; Temperature $20^{\circ} \mathrm{C}, \mathrm{pH}=8.5$ and Dissolved Oxygen $=5 \%$ leading to approximately $3 \mathrm{~g} / \mathrm{L}$ representing 30 times increase in the productivity compared to the amount obtained in shake flasks prior to optimization. The contribution of three factors in Taguchi experimental design showed that $\mathrm{pH}$ played a leading role than the other factors ( $\mathrm{pH} 34.99 \%$, dissolved oxygen $24.27 \%$ and temperature $22.62 \%$ ).

In the second step; the optimum levels achieved were applied to In-Situ Sterilization (20L) with precise control and online monitoring of the microbial behavior. The achieved yield upon the 
scaling up process was approximately $7 \mathrm{~g} / \mathrm{L}$ of $\mathrm{PG}$ after $19 \mathrm{hrs}$ from inoculating the bioreactor , end of log phase, representing 70 times more yield compared to the amount produced prior to optimization. The attained results confirms that; Taguchi experimental design is a good positive option for the optimization of biotechnological processes.

Taguchi experimental design was proven to enhance the production yield of different microbial products with fewer experimental runs including protease production by Bacillus subtilis HB04, alkaline protease production by Bacillus clausii, xylanase production by Bacillus cereus BSAlanddextransucrase production from Weissella confuse Cab3 [23-25] leading to considerable economy in time and cost for the process optimization.

Upon purification; the purity and the chemical structure of the obtained pigment were explored by means of spectrophotometric, NMR and FTIR spectrum methods. The purified PG showed maximum absorbance at $535 \mathrm{~nm}$ which is in line with the literature [12]. In addition; The chemical shift signals of ${ }^{1}$ H-NMR spectra obtained from Serratia sp AM8887 was agreed with reference produced by Serratia marcescens ATCC9986 [26]. The FTIR range for the purified PG demonstrated groups at $2909 \mathrm{~cm}^{-1}$ (methylene group), $1565 \mathrm{~cm}^{-1}$ (pyrrole ring) and $3463.65 \mathrm{~cm}^{-1}$ (amide group). Tops at 3400-3445 $\mathrm{cm}^{-1}$ are allotted for aliphatic alcohols, essential amines and amides while assimilation band at $1655 \mathrm{~cm}^{-1}$ related to $(\mathrm{C}=\mathrm{C})$ extending vibrations. From the range, the fundamental utilitarian gatherings of rough $\mathrm{PG}$ were pyrrole, methylene, alkane and alkene showing a high similarity to the PG produced by different Serratia strains [27,28]. The fingerprint region for the red pigment was characterized by medium-intensity bands at max 1728 $(\mathrm{C}=\mathrm{O}), 1263,1135(\mathrm{C}-\mathrm{O}$ and $\mathrm{C}-\mathrm{N}), 961$ and $802 \mathrm{~cm}^{-1}$. Broad absorption for $\mathrm{NH}$ was at $3445 \mathrm{~cm}^{-}$ 1 .

The in vitro antimicrobial and the antioxidant activities of the purified pigment showed a very promising results; as the pigment showed an antimicrobial activity against a wide range of antibiotic resistant microbes isolated from clinical samples and furthermore the pigment showed an antioxidant activity stronger than gallic acid and ascorbic acid. Applying PG in food industry could be beneficial in adding a natural food colorant with antimicrobial and antioxidant capabilities which could be advantageous and require no more additives for food protection.

The purified PG was found to have visible cytotoxic effect against breast cancer cell line (MCF7) and liver cancer cell line (HepG-2) when applying MTT assay. With an IC50 value of 5.4 $\mu \mathrm{g} / \mathrm{ml}$ for (HepG-2) cell line and $8.73 \mu \mathrm{g} / \mathrm{ml}$ for the (MCF-7) breast cell line; the PG produced 
by the isolate was found to be more efficient than the PG produced by the isolate Rugamonas rubra RR62 which showed no apoptotic activity against HepG-2 cell line when the pigment concentration is below $125 \mu \mathrm{g} / \mathrm{ml}$ [29] and more efficient than the PG produced by the isolate Serratia marcescens which has an $\mathrm{IC}_{50}$ of $40.76 \mu \mathrm{g} / \mathrm{ml}$ against the MCF-7 cell line [30]. Recently, the PG mode of action, as an anticancer, was revealed and it was reported to induce protein kinase $\mathrm{B}$ inhibition to down-regulate S-phase kinase-associated protein 2 (SKP2) in an independent manner. Our findings further implicate the potential for emerging PG as a novel class of SKP2-targeting anticancer agent [31]. 


\section{REFERENCES}

1. Cang, S.; Sanada, M.; Johdo, O.; Ohta, S.; Nagamatsu, Y.; Yoshimoto, A. High production of prodigiosin by Serratia marcescens grown on ethanol. Biotechnology letters 2000, 22, 1761-1765. DOI: 10.1023/A:1005646102723

2. Sumathi, C.; MohanaPriya, D.; Swarnalatha, S.; Dinesh, M.; Sekaran, G. Production of prodigiosin using tannery fleshing and evaluating its pharmacological effects. The Scientific World Journal 2014, . DOI: 10.1155/2014/290327

3. Maheswarappa, G.; Kavitha, D.; Vijayarani, K.; Kumanan, K. Prodigiosin as anticancer drug produced from bacteria of termite gut. Indian Journal of Basic and Applied Medical Research 2013, 3, 257-266.

4. Tomás, R.P.; Ruir, C.D.; Montaner, B. Prodigiosin induces cell death and morphological changes indicative of apoptosis in gastric cancer cell line hgt-1. Histology and histopathology 2001, 16, 415-421.

5. Elrazak, A.A.; Ward, A.C.; Glassey, J. Polyunsaturated fatty acid production by marine bacteria. Bioprocess and biosystems engineering 2013, 36, 1641-1652. DOI: 10.1007/s00449-013-0936-0

6. Fei, N.C.; Mehat, N.M.; Kamaruddin, S. Practical applications of taguchi method for optimization of processing parameters for plastic injection moulding: A retrospective review. ISRN Industrial engineering 2013, $462174, \quad 11$. http://dx.doi.org/10.1155/2013/462174

7. Osman, Y.; Elrazak, A.A.; Khater, W. Bioprocess optimization of microbial biopolymer production. Journal of Biobased Materials and Bioenergy 2016, 10, 119-128. DOI: https://doi.org/10.1166/jbmb.2016.1582

8. Venil, C.; Lakshmanaperumalsamy, P. Taguchi experimental design for medium optimization for enhanced protease production by Bacillus subtilis HB04. e-Journal of Science \& Technology 2009.

9. Yong-jun, X.; Lian-zhong, A. Determination of prodigiosin in fermentation broth by HPLC. Modern Food Science and Technology 2013, 11, 039. 
10. Venil, C.K.; Lakshmanaperumalsamy, P. An insightful overview on microbial pigment, prodigiosin. Electronic Journal of Biology 2009, 5, 49-61.

11. Naik, C.; Srisevita, J.; Shushma, K.; Farah, N.; Shilpa, A.; Muttanna, C.; Darshan, N.; Sannadurgappa, D. Peanut oil cake: A novel substrate for enhanced cell growth and prodigiosin production from Serratia marcescens CF-53. Journal of Biological Research 2012, 2(6), 549-557

12. Mohammed, H.; Naseer, J.; Aruna, K. Study on optimization of prodigiosin production by Serratia marcescens MSK1 isolated from air. International Journal of Advanced Biotechnology Research 2012, 2, 671-680.

13. Namazkar, S.; Garg, R.; Ahmad, W.Z.; Nordin, N. Production and characterization of crude and encapsulated prodigiosin pigment. International Journal of Chemical Sciences and Applications 2013, 3, 116-129.

14. Casullo de Araújo, H.W.; Fukushima, K.; Takaki, G.M.C. Prodigiosin production by Serratia marcescens UCP 1549 using renewable-resources as a low cost substrate. Molecules 2010, 15, 6931-6940. Doi:10.3390/molecules15106931

15. Ibrahim, D.; Nazari, T.F.; Kassim, J.; Lim, S.H. Prodigiosin-an antibacterial red pigment produced by Serratia marcescens IBRL USM 84 associated with a marine sponge Xestospongia testudinaria. Journal of Applied Pharmaceutical Science 2014, 4, 001-006. DOI: $10.7324 / J A P S .2014 .40101$

16. Vora, J.; Jain, N.; Modi, H. Identification and characterization of pigment producing strain Kocuria KM243757 \& JO1 KM216829 from Kharaghoda soil. International Journal of Current Microbiology and Applied Sciences 2015, 4(9), 850-859

17. Mosmann, T. Rapid colorimetric assay for cellular growth and survival: Application to proliferation and cytotoxicity assays. Journal of immunological methods 1983, 65, 55-63. https://doi.org/10.1016/0022-1759(83)90303-4

18. Vijayan, P.; Raghu, C.; Ashok, G.; Dhanaraj, S.; Suresh, B. Antiviral activity of medicinal plants of nilgiris. Indian Journal of medical research 2004, 120, 24-29.

19. Alihosseini, F.; Lango, J.; Ju, K.S.; Hammock, B.D.; Sun, G. Mutation of bacterium Vibrio gazogenes for selective preparation of colorants. Biotechnology progress 2010, 26, 352-360. doi: 10.1002/btpr.346 
20. Song, M.J.; Bae, J.; Lee, D.S.; Kim, C.H.; Kim, J.S.; Kim, S.W.; Hong, S.I. Purification and characterization of prodigiosin produced by integrated bioreactor from Serratia sp. KH-95. Journal of bioscience and bioengineering 2006, 101, 157-161. https://doi.org/10.1263/jbb.101.157

21. Guryanov, I.; Karamova, N.; Yusupova, D.; Gnezdilov, O.; Koshkarova, L. Bacterial pigment prodigiosin and its genotoxic effect. Russian Journal of Bioorganic Chemistry 2013, 39, 106-111. DOI: 10.1134/S1068162012060040

22. Wang, D.S.; Koo, T.Y.; Lin, I.P.; Liu, H.R.; Chou, C.Y. Note: Determination of nattokinase production condition using taguchi parameter design. Food science and technology international 2006, 12, 215-220. DOI: 10.1177/108201320065993

23. Oskouie, S.F.G.; Tabandeh, F.; Yakhchali, B.; Eftekhar, F. Enhancement of alkaline protease production by Bacillus clausii using taguchi experimental design. African Journal of Biotechnology 2007, 6, 2559-2564.

24. Mandal, A.; Kar, S.; Dutta, T.; Pati, B.R.; Mondal, K.C.; Mohapatra, P.K.D. Parametric optimization of submerged fermentation conditions for xylanase production by Bacillus cereus BSA1 through taguchi methodology. Acta Biologica Szegediensis 2015, 59, 189195.

25. Shukla, S.; Goyal, A. Development of efficient fermentation process at bioreactor level by taguchi's orthogonal array methodology for enhanced dextransucrase production from Weissella confusa CAB3. Advances in Microbiology 2012, 2, 277. DOI: 10.4236/aim.2012.23033

26. Gur'ianov, I.; Karamova, N.; Iusupova, D.; Gnezdilov, O.; Koshkarova, L. Bacterial pigment Prodigiosin and its genotoxic effects. Bioorganicheskaia khimiia 2012, 39, 121 128. DOI: $10.7868 / \mathrm{S} 0132342312060048$

27. Ahmad, W.A. Production and characterization of crude and encapsulated prodigiosin pigment. International Journal of Chemical Sciences and Applications 2013, 4, 116-129.

28. Aruldass, C.A.; Venil, C.K.; Zakaria, Z.A.; Ahmad, W.A. Brown sugar as a low-cost medium for the production of prodigiosin by locally isolated Serratia marcescens UTM1. International Biodeterioration \& Biodegradation 2014, 95, 19-24. https://doi.org/10.1016/j.ibiod.2014.04.006 
29. Hassani, H.H. Cytotoxicty and dna fragmentation in cancer cell lines, HEP-2 and AMN3, induced by a novel maroon pigment from mutant strain of Rugamonas rubra RR62. Journal of Al-Nahrain University 2011. 14, 110-114

30. Athavale, M.A.; Somaiya, S.S.; More, G.A.; Satish, S.; Srivastava, S.A. Comparitive invitro cytotoxicity of red pigment extract of Serratia. Marcescens on breast and prostrate cancer cell lines. International Journal of Current Pharmaceutical Research 2013, 5, $140-143$.

31. Hsieh, H.Y.; Shieh, J.J.; Chen, C.J.; Pan, M.Y.; Yang, S.Y.; Lin, S.C.; Chang, J.S.; Lee, A.Y.L.; Chang, C.C. Prodigiosin down-regulates SKP2 to induce p27kip1 stabilization and antiproliferation in human lung adenocarcinoma cells. British journal of pharmacology 2012, 166, 2095-2108. Doi: 10.1111/j.1476-5381.2012.01921.x. 